\title{
Synthesis, Characterization and Ammonia Sensing Properties of Mn Doped Zinc Oxide Nano- Composite
}

\author{
Saroj D. Patil ${ }^{1}$, R. B. Waghulade ${ }^{2}$, R. S. Khadayate ${ }^{3}$ \\ ${ }^{1}$ GF's - Godavari College of Engineering, Jalgaon 425001, Maharashtra, India \\ ${ }^{2}$ D.N.C.V.P's Arts, Commerce and Science College, Jalgaon 425001, Maharashtra, India \\ ${ }^{3}$ G.D.M. Arts, K.R.N. Commerce, M.D. Science College, Jamner, Dist-Jalgaon, Maharashtra, India
}

\begin{abstract}
This paper reports the synthesis, characterization and ammonia sensing properties of nano-sized Zinc oxide (ZnO) and its nano composite Mn doped $\mathrm{ZnO}$. A simple chemical co-precipitation method is used for the synthesis of ZnO nano-sized powder and its nano-composite. Zinc Acetate $\left(\mathrm{Zn}\left(\mathrm{C}_{2} \mathrm{H}_{3} \mathrm{O}_{2}\right)_{2}\right)$, Manganese acetate $\left(\mathrm{Mn}\left(\mathrm{CH}_{3} \mathrm{COO}\right)_{2} \cdot 2 \mathrm{H}_{2} \mathrm{O}\right)$ and the sodium hydroxide $(\mathrm{NaOH})$ were used as a starting materials and double distilled water as a carrier. The resulting nano-sized powder was characterized by $x$-ray diffraction (XRD) measurements, transmission electron microscopy (TEM) and energy dispersive $x$-ray (EDAX). The $\mathrm{NH}_{3}$ sensing properties of the synthesized nano-sized $\mathrm{ZnO}$ were investigated at different operating temperatures and $\mathrm{NH}_{3}$ concentrations. The effects of operating temperature on the sensitivity, selectivity, response and recovery of the sensor in the presence of $\mathrm{NH}_{3}$ and other gases were studied and discussed.
\end{abstract}

Keywords: Nano-sized Mn doped $\mathrm{ZnO}$, Chemical co-precipitation, XRD, TEM, EDAX, $\mathrm{NH}_{3}$ gas sensor

\section{Introduction}

Over the past few years, the synthesis and functionalism of nanostructures have attracted great interest due to their significant potential application. Recently, semiconductor nanostructures have attracted much interest due to their extraordinary physical properties and potentials for diverse electronic and photonic device applications [1,2]

Zinc oxide $(\mathrm{ZnO})$, one of the very important and versatile semiconductors with direct band gap of gap of $3.37 \mathrm{eV}$ [3] and a large exciton binding energy of $60 \mathrm{meV} \mathrm{[4]} \mathrm{at} \mathrm{room}$ temperature (RT) is a promising candidate for functional components of devices and materials in photonic crystals [5], gas sensors [6], light emitting diodes [7], solar cells [8, 9], lasers [2], varistors [10] and photoelectrochemical cells [11]. Over the past few years, $\mathrm{ZnO}$ nanomaterials with various interesting structures and properties have been synthesized, such as nanoparticles [12], nanorods [13], nanobelts, nanocombs [14], nanowires [15], and tetrapod nanostructures [16]. It is well known that doping a selective element into $\mathrm{ZnO}$ is the primary method for controlling the properties of the semiconductor such as band gap or electrical conductivity, and to increase the carrier concentration for electronic applications where a higher carrier concentration is required. Recently, many studies have focused on the doping of transition metals (TMs) such as $\mathrm{Mn}, \mathrm{Ni}, \mathrm{Fe}$, Co and $\mathrm{Cr}$ into $\mathrm{ZnO}$ due to the potential applications in spintronics [17].

Ammonia is used in many chemical industries, fertilizer factories, refrigeration systems, food processing, medical diagnosis, fire power plants etc. A leak in the system can result the health hazards. Ammonia is harmful and toxic [1822] in nature. Detection of low concentration of ammonia is not only important from the points discussed above but also, it is very important from the view of chemical pollution in the production of silicon devices in clean rooms. It is therefore necessary to monitor ammonia gas and to develop the ammonia gas sensors. Efforts are made to develop the $\mathrm{ZnO}$-based gas sensors, which should detect ammonia at low temperature.

Few room temperature ammonia sensors are already available [23, 24], but having comparatively low response. Despite of high sensitivity, selectivity and long-term stability, the main drawback of such sensors is that they are operated at high temperature $\left(>300^{\circ} \mathrm{C}\right)$. Also, the noble metal additives like $\mathrm{Pt}, \mathrm{Pd}, \mathrm{Au}$, and $\mathrm{Ag}$ to a base material like $\mathrm{ZnO}$, for the modification, increases the cost of the sensors. Therefore the applicability of these sensors remains limited. Hence the sensors operable at room temperature with low cost metal additives must be developed for large applicability.

\section{Experimental}

\subsection{Preparation of nano-powder}

Undoped and Mn-doped zinc oxide nanocrystals have been synthesized in aqueous solutions by using zinc acetate $(\mathrm{Zn}$ $\left.\left(\mathrm{CH}_{3} \mathrm{COO}\right)_{2}, 2 \mathrm{H}_{2} \mathrm{O}\right)$, manganese acetate $\left(\mathrm{Mn}\left(\mathrm{CH}_{3} \mathrm{COO}\right)_{2}\right.$, $2 \mathrm{H}_{2} \mathrm{O}$ ) and sodium hydroxide $(\mathrm{NaOH})$ as the starting materials. Aqueous solution of zinc acetate and manganese acetate at room temperature was stirred using a magnetic stirrer. Then the $\mathrm{NaOH}$ solution was added slowly drop wise to aqueous solution of zinc acetate and manganese acetate under constant stirring until the final solution $\mathrm{pH}$ value of about 8 was achieved. The resulting precipitate was filtered and washed three to four times using double distilled water to remove impurities. The hydroxide, thus formed was dried at $100^{\circ} \mathrm{C}$ and grinded into a powder, which is the precursor. 


\section{International Journal of Science and Research (IJSR) \\ ISSN (Online): 2319-7064 \\ Index Copernicus Value (2013): 6.14 | Impact Factor (2015): 6.391}

The precursor was calcined in air at different temperatures of $400^{\circ} \mathrm{C}, 600^{\circ} \mathrm{C}, 800^{\circ} \mathrm{C}$ and $1000^{\circ} \mathrm{C}$ for 2 hours to produce nano-crystalline powders with different grain size.

\subsection{Preparation of Pallet}

The nano powder was be pressed into pallete having thickness $0.120 \mathrm{~cm}$ under pressure of 5 tons using the Pelletizer machine and the ohmic contacts were done with the silver paste to form the sensing elements.

\subsection{Characterisation}

The structure of the calcined powder was investigated by using X-ray diffraction (XRD) technique. The X-ray diffraction patterns were recorded with a Rigaku diffractometer (Miniflex Model, Rigaku, Japan) having $\mathrm{Cu}$ $\mathrm{K}_{\alpha} \quad(\lambda=0.1542 \mathrm{~nm})$. The crystalline size was estimated from the broadening of $\mathrm{Mn}-\mathrm{ZnO}$ (101) diffraction peak $(2 \theta$ $=36.31^{\circ} \mathrm{C}$ ) using Debye-Scherrer's formula. The transmission electron microscopy (TEM) was used to determine the particle size and the morphology of the nanosized powder with JEOL 1200 EX. The composition of elements like $\mathrm{Zn}, \mathrm{O}$ and $\mathrm{Mn}$ is confirmed by energy dispersive X-ray (EDAX) spectra.

\subsection{Details of the gas sensing system}

The gas sensing was carried out on these sensing elements with laboratory design static gas chamber to sense different gases in air atmosphere. The sensing element was placed directly on the metal plate. The temperature of the metal plate was varied with the help of heater and the temperature was measured with the help of aluminium-chromel thermocouple. The known volume of the sensing gas was introduced into the gas chamber. The electrical resistance of the sensing element was measured before and after exposer to gas using sensitive digital multimeter (METRAVI 603)

\section{Materials Characterisations}

\subsection{Structural Properties (X-ray Diffraction)}

The XRD pattern of the calcinied powder at $400^{\circ} \mathrm{C}$ for 2 hour is shown in Fig. 1.

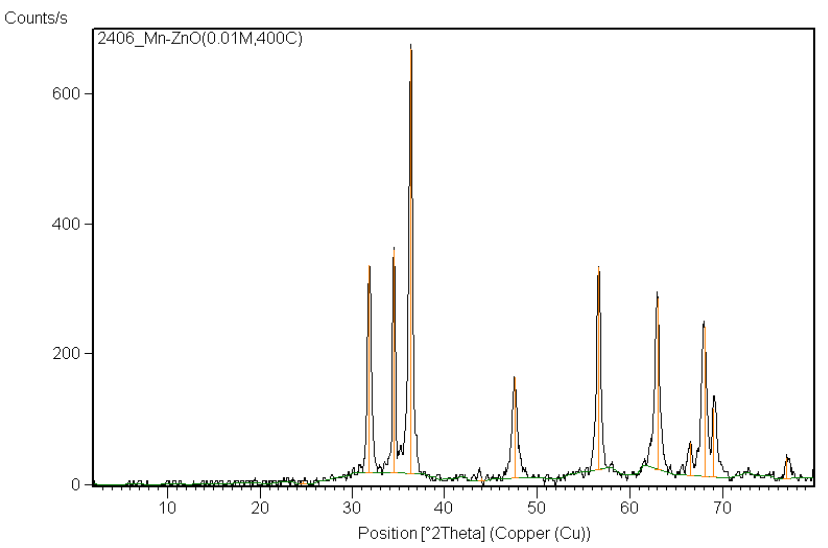

Figure 1: XRD pattern of $\mathrm{Mn}$ doped $\mathrm{ZnO}$ calcinied at $400^{\circ} \mathrm{C}$
The XRD indicates the major diffraction peaks at $2 \theta$ values of $31.80^{\circ}, 34.46^{\circ}, 36.31^{0}, 47.58^{\circ}, 56.67^{0}, 63.01^{0}, 68.98^{\circ}$, and $76.95^{\circ}$ etc which are attributed to the formation of $\mathrm{Mn}-\mathrm{ZnO}$. The peak positions are agree well with cassiterite structure. From the XRD data it is clear that, there are no peaks corresponding to $\mathrm{Mn}^{2+}$ ions. This indicates that there is no alteration of wurtzite structure of $\mathrm{ZnO}$ due to substitution of $\mathrm{Mn}^{2+}$ ions. The crystallite size was calculated by using the Scherrer formula -

$$
t=\frac{k \lambda}{B \cos \theta}
$$

where $\mathrm{t}$ is the average size of the crystallite, assuming that the grains are spherical, $\mathrm{k}$ is $0.9, \lambda$ is the wavelength of $\mathrm{X}$ ray radiation, $\mathrm{B}$ is the peak full width at half maximum (FWHM) and $\theta$ is the angle of diffraction. The crystalline size of the powder calcinied at $400^{\circ} \mathrm{C}$ is found to be minimum and it is $\sim 35.31 \mathrm{~nm}$ scale.

\subsection{TEM Micrograph}

The TEM micrograph of the powder calcinied at $400^{\circ} \mathrm{C}$ is shown in Fig. 2. The TEM micrograph shows clearly that the particle size of powder calcinied at $400^{\circ} \mathrm{C}$ is in $\mathrm{nm}$ scale. This result is in well agreement with the crystallite size calculated using the XRD data.

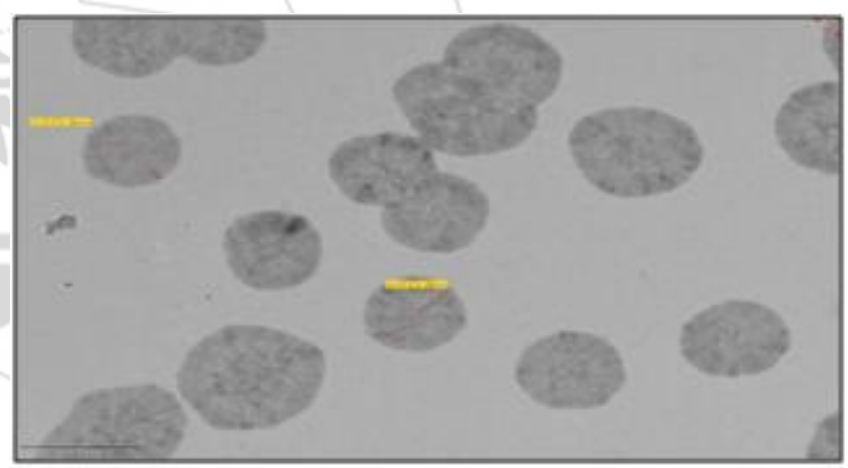

Figure 2: TEM micrograph of $\mathrm{Mn}$ doped $\mathrm{ZnO}$ calcinied at $400^{\circ} \mathrm{C}$ for $2 \mathrm{~h}$

\subsection{Quantitative elemental analysis}

The EDAX spectram of nano-sized $\mathrm{Mn}-\mathrm{ZnO}$ is as shown in Fig. 3. The EDAX analysis indicates the presence of signals due to the $\mathrm{Zn}(33.95 \%)$, Mn (5.43\%), and O (60.62\%), which proves that the formation of the nanocomposote without any impurities. 


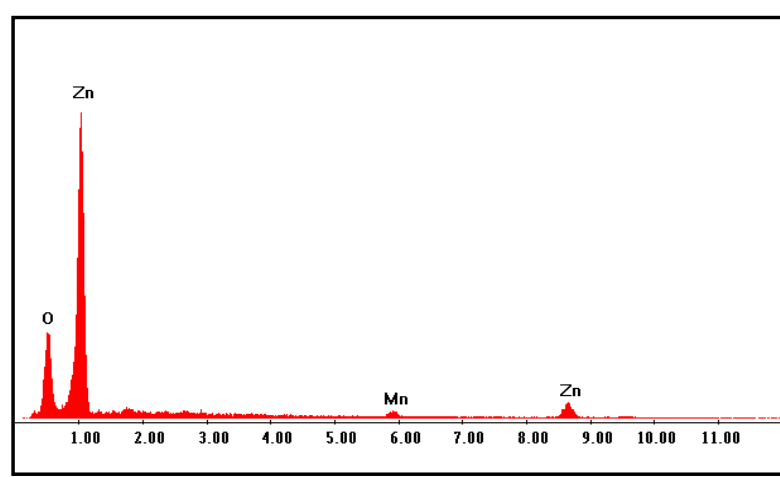

Figure 3: EDAX spectram of Mn doped $\mathrm{ZnO}$

\section{Gas sensing performance of the sensor}

\subsection{Sensing performance of pure $\mathrm{ZnO}$}

The gas response of the sensing element is defined as:

$$
S(\%)=\frac{R_{g}-R_{a}}{R_{a}} \times 100
$$

where $R_{a}$ and $R_{g}$ are the resistance values of the sensor element in air and in the presence gaseous environment.

Fig 4 shows the variation of gas response with operating temperature of pure $\mathrm{ZnO}$ to $2500 \mathrm{ppm}$ of ammonia gas. The gas response increases with increase in operating temperature and it is maximum at $400^{\circ} \mathrm{C}$. For pure $\mathrm{ZnO}$ gas response is $19.64 \%$ at $400^{\circ} \mathrm{C}$ to $\mathrm{NH}_{3}$. The $\mathrm{NH}_{3}$ gas response of pure $\mathrm{ZnO}$ is related to oxygen adsorption on surface. The oxygen adsorption is poor for pure $\mathrm{ZnO}$ and shows poor response to $\mathrm{NH}_{3}$. ZnO requires more temperature to adsorb oxygen ions. Hence it would have higher response at higher operating temperature [26].

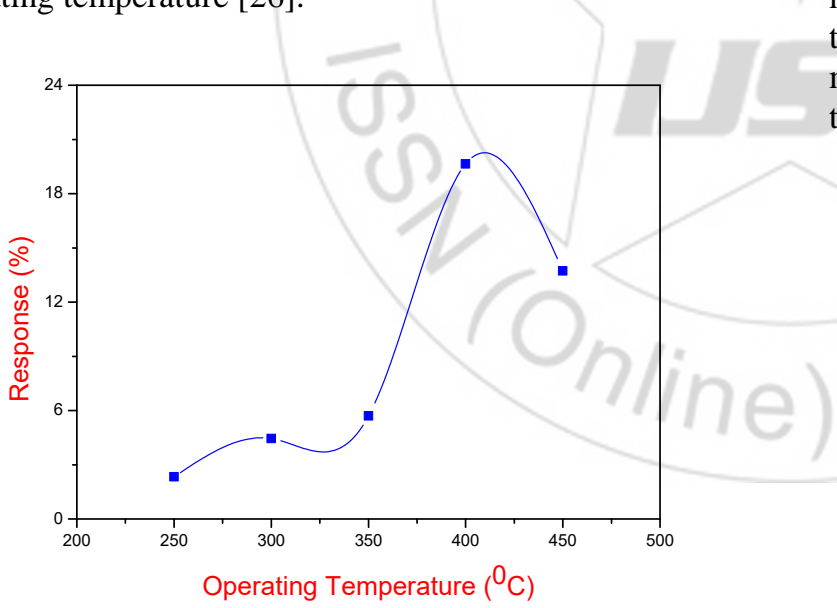

Figure 4: Effect of operating temperature on gas response of pure Nano $\mathrm{ZnO}$

\subsection{Sensing performance of $\mathrm{Mn}$ doped $\mathrm{ZnO}$}

\section{A. Effect of operating temperature}

Fig 5 shows the effect of operating temperature on gas response to $\mathrm{NH}_{3}$ gas $(2500 \mathrm{ppm})$ for $\mathrm{Mn}$ doped $\mathrm{ZnO}$. Mn doped $\mathrm{ZnO}$ shows maximum response $50.82 \%$ to $90^{\circ} \mathrm{C}$. At this temperature there would be no adsorption, hence the oxygen adsorption-desorption is not employed to sense the $\mathrm{NH}_{3}$ gas. When raising the temperature above $90^{\circ} \mathrm{C}$, the moisture from the surface evaporates and hence the response would decreases [27].
In comparision of Pure $\mathrm{ZnO}$ there is increased sensing response of the $\mathrm{Mn}$-doped $\mathrm{ZnO}$. This is might be due to the decreased crystallite size and enhanced electron density [28]. This may also be due to the excess donor concentrations induced by $\mathrm{Mn}$ doping $[29,30]$. Since $\mathrm{Mn}^{2+}$ has lower ionization energy than that of $\mathrm{ZnO}$, it might have influenced the oxygen adsorption / desorption process [31]. Hence Mn doped $\mathrm{ZnO}$ showed an excellent response than undoped $\mathrm{ZnO}$ film.

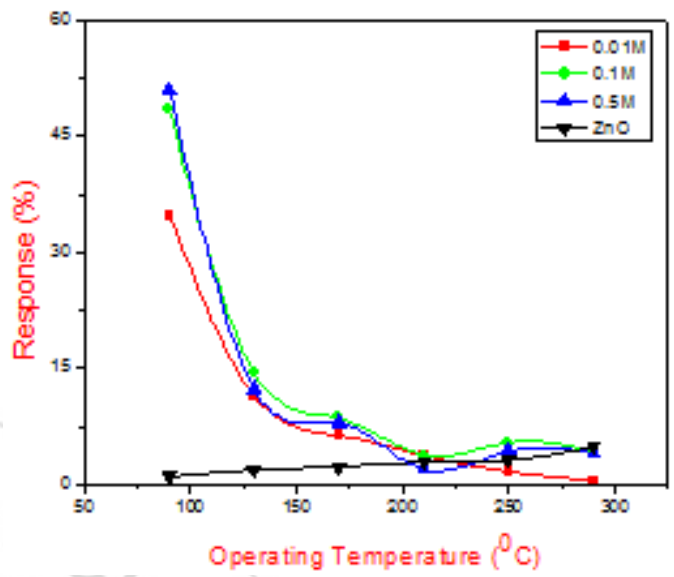

Figure 5: Effect of operating temperature on gas response of $\mathrm{Mn}$ doped $\mathrm{ZnO}$

\section{B. Effect of gas concentration}

Fig 6 shows the effect of $\mathrm{NH}_{3}$ gas concentration at $90^{\circ} \mathrm{C}$ to $\mathrm{Mn}$ doped $\mathrm{ZnO}$. This sensor was exposed to varying concentrations of $\mathrm{NH}_{3}$ it shows continuously increase in gas response with increase in concentrations. This is due to, the low gas concentration gives a lower surface coverage of gas molecules which results into lower surface reaction between the adsorbed oxygen species at surface and the gas molecules. The increase in the gas concentration increases the surface reaction due to a large surface coverage [32].

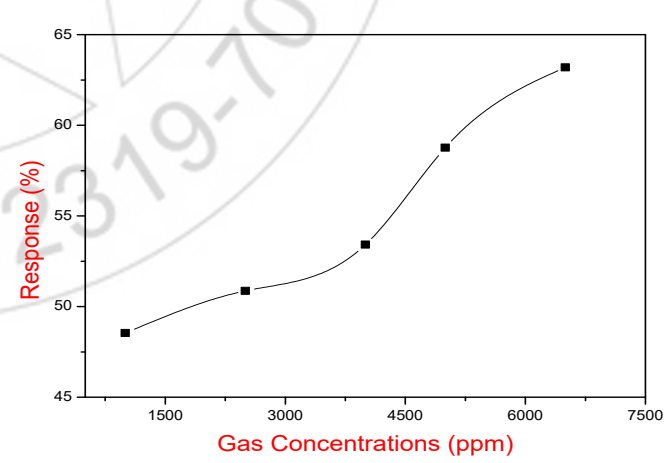

Figure 6: Dependance of sensitivit on $\mathrm{NH}_{3}$ gas concentration at operating temperating $90^{\circ} \mathrm{C}$

\section{Selectivity of $\mathrm{NH}_{3}$ gas}

Selectivity or specificity is defined as the ability of a sensor to respond to certain gas in the presence of other different gases. Fig 7 shows the selectivity of $\mathrm{Mn}$ doped $\mathrm{ZnO}$ for $\mathrm{NH}_{3}$ sensor. Sensor shows maximum selectivity among the various gases like LPG, Methanol, acetone and $\mathrm{H}_{2} \mathrm{~S}$ at $90^{\circ} \mathrm{C}$. 


\section{International Journal of Science and Research (IJSR) \\ ISSN (Online): 2319-7064}

Index Copernicus Value (2013): 6.14 | Impact Factor (2015): 6.391

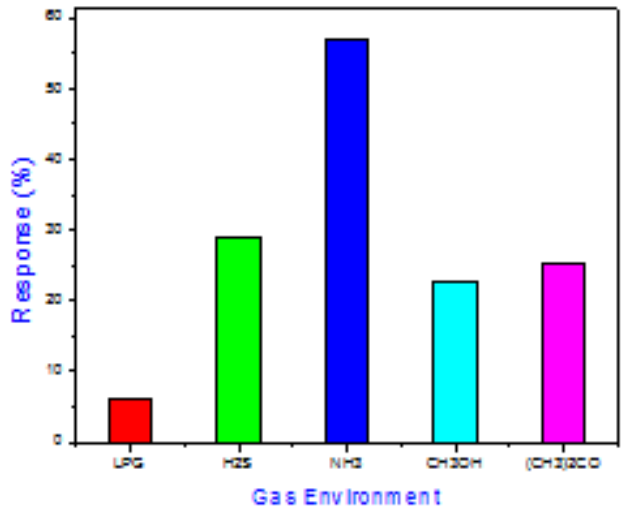

Figure 7: Selectivity curve of $\mathrm{Mn}$ doped $\mathrm{ZnO}$ to2500 ppm to various gases

\section{Response and recovery time}

Response time is defined as the time required to reach $90 \%$ of the maximum increase in response when the gas is turned on. And recovery time is defined as the time required to get back $90 \%$ of the maximum response in air. Fig 8 shows the quick response $(10 \mathrm{Sec}$.) and fast recovery $(50 \mathrm{Sec}$.) to $\mathrm{NH} 3$ gas.

When ammonia is exposed, due to surface reaction of ammonia with physisorbed $\mathrm{H}_{2} \mathrm{O}$ or by conductivity through $\mathrm{NH}_{4}{ }^{+}$cations, resistance gets decreases. It constitutes the proton conductivity leading to decrease in resistance. This would decrease the barrier height among the $\mathrm{MnO}_{2}-\mathrm{ZnO}$.

$$
\mathrm{NH}_{3}+\mathrm{H}_{2} \mathrm{O} \longrightarrow \mathrm{NH}_{4} \mathrm{OH}
$$

During the surface reaction, produced $\mathrm{NH}_{4} \mathrm{OH}$ is volatile in nature. This high volatile nature explains the quick response and fast recovery time of the sensor [25].

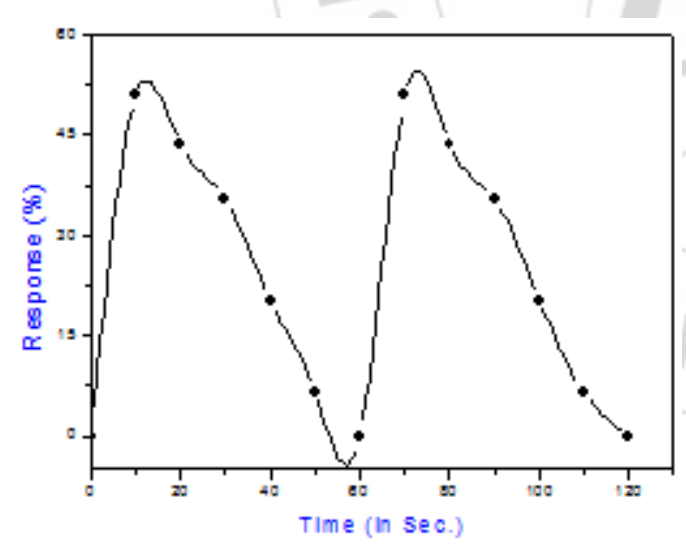

Figure 8: Response and recovery of sensor for $\mathrm{NH}_{3}$ gas

\section{Conclusions}

The following main findings resulted from the present investigation -

- We have successfully synthesized the $\mathrm{Mn}$ doped $\mathrm{ZnO}$ nano-composite at low cost by using a chemical coprecipitation method. Zinc Acetate $\left(\mathbf{Z n}\left(\mathbf{C}_{2} \mathbf{H}_{3} \mathbf{O}_{2}\right)_{2}\right)$, mangnese acetate $\left(\mathbf{M n}\left(\mathbf{C H}_{3} \mathbf{C O O}\right)_{2} \cdot \mathbf{2 H}_{2} \mathbf{O}\right)$ and the sodium hydroxide $(\mathrm{NaOH})$ were used as a starting materials and double distilled water as a carrier. The resulting powder was characterized by XRD measurements, TEM and EDAX

- The crystallite size is found to be $35.31 \mathrm{~nm}$ when the asprepared powder was calcinied at $400^{\circ} \mathrm{C}$ for $2 \mathrm{~h}$.

- The operating temperature significantly affects the sensitivity of the synthesized $\mathrm{Mn}$ doped $\mathrm{ZnO}$ nanocomposite to the $\mathrm{NH}_{3}$. The sensitivity to $2500 \mathrm{ppm}$ of $\mathrm{NH}_{3}$ is maximum at an operating temperature $90^{\circ} \mathrm{C}$ and it was found to be $\sim 50.82 \%$. The response time was nearly $10 \mathrm{~s}$ and the recovery time was found to be $50 \mathrm{~s}$.

- It was shown that $\mathrm{Mn}$ doped $\mathrm{ZnO}$ nano-composite can be reliably used to monitor the concentration of $\mathrm{NH}_{3}$ over the range (1000-6500 ppm).

\section{References}

[1] X. Duan, Y. Huang, Y. Cui, J.Wang and C.M. Lieber: Nature, 2001, 409, 66.

[2] H.M. Huang, S. Mao, H. Feick, H. Yan, H. Wu and H. Kind: Science, 2001, 292, 1897.

[3] Meyer B K et al 2004 Physica Status Solidi B 241231

[4] Madelung O (ed) 1992 Data in Science and Technology: Semiconductors (Berlin: Springer)

[5] Chen Y, Bagnall D and Yao T 2000 Mater. Sci. Eng. B 75190

[6] Dayan N J, Sainkar S R, Karekar R N and Aiyer R C 1998 Thin Solid Films 325254

[7] Saito N, Haneda H, Sekiguchi T, Ohashi N, Sakaguchi L and Koumoto K 2002 Adv. Mater. 14418

[8] Chopra K L and Das S R 1983 Thin Film Solar Cells (New York: Plenum) 321

[9] Salam S, Islam M, Alam M, Akram A, Ikram M, Mahmood A, Khan M and Mujahid M 2011 Adv. Nature Sci.: Nanosci. Nanotechnol. 2045001

[10]Hung N T, Quang N D and Bernik S 2001 Mater. Res. 162817

[11]Chieng D T, Long P D, Lam N H and Hoi P V 2010 Adv. Nature Sci.: Nanosci. Nanotechnol. 1035010

[12]Dong L F, Cui L Z and Zhang Z K 1997 Nanostruct. Mater. 8815

[13] Wu J J and Liu S C 2002 Adv. Mater. 14215

[14] Yang P D, Yan H Q, Mao S, Russo R, Johnso J, Saykally R, Morris N, Pham J R, He R and Choj H J 2002 Adv. Funct.Mater. 12323

[15] Kong Y C, Yu D P, Zhang B, Fang W and Feng S Q 2001 Appl. Phys. Lett. 78407

[16]Dai Y, Zhang Y, Li Q K and Nan C W 2002 Chem. Phys. Lett. 83358

[17] Bauer C, Boschloo G, Mukhtar E and Hagfeldt A 2001 J.Phys. Chem. B 1055585

[18] L. R. Narasimhan, W. Goodman, C. Kumar and N. Patel, Proceedings of the National Academy of Sciences, Vol. 98, No. 8, 2001, pp. 4617-4621. doi:10.1073/pnas.071057598

[19]R. E. de la Hoz, D. P. Schueter and W. N. Rom, American Journal of Indus-trial Medicine, Vol. 29, 1996, pp. 209-214. doi:10.1002/(SICI)10970274(199602)29:2<209::AID-AJIM12>3.0.CO;2-7

[20]C. M. Leung and C. L. Foo, Annals Academy of Medicine Singapore, Vol. 21, 1992, pp. 624-629. 


\section{International Journal of Science and Research (IJSR) \\ ISSN (Online): 2319-7064}

Index Copernicus Value (2013): 6.14 | Impact Factor (2015): 6.391

doi:10.1289/ehp.99107617

[21] 21 R. A. Michaels, Environmental Health Perspectives, Vol. 107, No. 8, 1999, pp. 617-627.

[22] L. G. Close, F. I. Catlin and A. M. Cohn, Archives of Otolaryngology, Vol. 106, No. 3, 1980, pp. 151-158.

[23] S.Durgajanani, B.G. Jeyaprakash, R.J. Bosco Balaguru, Influence of precursor concentration on structural, morphological and electrical properties of spray deposited $\mathrm{ZnO}$ thin films, Cryst. Res. Technol. 46 (2011) 685-690

[24]P.Singh, A. Kaushal, D. Kaur, Mn-doped ZnO nanocrystalline trhin films prepared by ultrasonic spray pyrolysis, J. Alloy Compd. 471 (2009) 11-15

[25] S. Senthilkumar, K. Rajendran, S. Banerjee, T.K. Chini, V. Sengodan, Influence of $\mathrm{Mn}$ doping on the microstructure and optical property of $\mathrm{ZnO}$, Mater. Sci. Semicond. Process, 11 (2008) 6-12

[26] D. R. Patil, L. A. Patil and P. P. Patil, Sensors and Actuators B, Vol. 126, 2007, pp. 368-374. doi:10.1016/j.snb.2007.03.028

[27] G. S. Trivikrama Rao and D. Tarakarama Rao, Sensors and Actuators B, Vol. 55, 1999, pp. 166-169. doi:10.1016/S0925-4005(99)00049-0

[28] L. A. Patil, L. S. Sonawane and D. G. Patil Journal of Modern Physics,2011, 2, 12151221,doi:10.4236/jmp.2011210150

[29] X. Peng, J. Chu, B. Yang, P. X. Feng, Sens. Actuat. B 174 (2012) 258.

[30] D. Sivalingam, J. B. Gopalakrishnan, J. B. B. Rayappan, Sens. Actuat. B 166-167 (2012) 624.

[31] X. Peng, J. Chu, B. Yang, P. X. Feng, Sens. Actuat. B 174 (2012) 258.

[32] Y. Mao, S. Ma, X. Li, C. Wang, F. Li, X. Yang, J. Zhu, L. Ma, Appl. Surf. Sci. 298 (2014) 109. 